\title{
LINGUISTIC EVALUATION OF PUPIL'S KNOWLEDGE
}

\section{Zdeňka KRIŠOVÁ}

\begin{abstract}
The evaluation is a natural part of any educational activity. It is often expressed quantitatively evaluation stage (usually a sign of $1-5$, or AF point), but increasingly also applied qualitative assessment - verbal (language), which provides comprehensive information about student and better able to capture their individual progress. Evaluation of student knowledge level should always be objective, should motivate the creative student activities, increase his interest in teaching, strengthen its activity. Properly assess each pupil in the teaching process is extremely demanding and responsible, so teachers are always looking for ways to improve their work. One possibility is the use of information technology as a means of supporting the right decision about the quality of teacher knowledge of the pupil. Expert systems as programs that simulate the decision-making activity of experts to solve highly complex, highly focused problem-solving, can be a solution to this problem to good use. As part of this post was created fuzzy logic expert system for assessing the level of knowledge of the language learner and computer simulation was performed language model of the evaluation process.
\end{abstract}

Key words: evaluation, expert systems, expert knowledge, fuzzy set, linguistic fuzzy rule, fuzzy model, fuzzy logic, approximate reasoning

\section{JAZYKOVÉ HODNOCENÍ ZNALOSTÍ ŽÁKA}

Resumé: Hodnocení je přirozenou součástí každé výchovně-vzdělávací činnosti. Je často vyjádřeno kvantitativně hodnotícím stupněm (nejčastěji známkou 1-5, či písmenem A-F), ale stále více se uplatňuje i hodnocení kvalitativní - slovní (jazykové), které podává komplexnější informace o žákovi a dokáže lépe postihnout jeho individuální pokrok. Hodnocení úrovně znalostí žáka by mělo být vždy objektivní, mělo by žáka motivovat k tvořivé činnosti, zvyšovat jeho zájem o výuku, posilovat jeho aktivitu. Správně ohodnotit každého žáka ve vyučovacím procesu je však nesmírně náročné a zodpovědné, proto učitelé stále hledají způsoby, jak svoji práci zkvalitnit. Jednou z možností je využití informačních technologí jako podpůrného prostředku pro správné rozhodnutí učitele o kvalitě znalostí žáka. Expertní systémy jako programy, které simulují rozhodovací činnost expertů při řešení velmi složitých, úzce problémově zaměřených úloh, se dají k řešení tohoto problému dobře využít. $\mathrm{V}$ rámci tohoto př́spěvku byl vytvořen fuzzy-logický expertní systém pro jazykové hodnocení úrovně znalostí žáka a byla provedena počítačová simulace jazykového modelu procesu hodnocení.

Klíčová slova: hodnocení, expertní znalosti, expertní systémy, fuzzy množina, jazykové fuzzy pravidlo, fuzzy model, fuzzy logika, přibližné usuzování

\section{1 Úvod}

Hodnocení žáků je náročný proces, který je součástí výchovně vzdělávacího procesu a učitelé jej vykonávají průběžně po celý školní rok. Cílem hodnocení je poskytnout žákovi zpětnou vazbu, aby získal informace o tom, co se naučil, zvládl, v čem se zlepšil, ale také $\mathrm{v}$ čem chybuje, a jak má postupovat při odstraňování nedostatků. Hodnocení sleduje individuální pokrok žáka, hodnotí se předem stanovené požadavky ve vztahu k jeho věku a možnostem. Hodnocení nesmí vést ke srovnávání žáka se spolužáky, rozdělování na úspěšné a neúspěšné žáky, snižování sebedůvěry a důstojnosti žáka. Mělo by být naopak pro žáky motivující, mělo by posilovat zájem o výuku, aktivitu, tvořivé činnosti i radost $\mathrm{z}$ úspěchu. Hodnocení žáků probíhá pomocí klasifikace (kvantitativní hodnocení), lépe je však vystiženo slovním hodnocením (kvalitativní hodnocení), které poskytuje celistvější a komplexnější informace o jeho silných a slabých stránkách a dokáže lépe postihnout individuální pokrok každého žáka [2],[5].

Pravidla a kritéria hodnocení výsledků vzdělávání žáků přesně vymezuje školní dokumentace (školní řád, studijní řád), prresto právě slovní (jazykové) hodnocení, založené na subjektivních pocitech pedagogů, může vést $\mathrm{k}$ pocitům frustrace a nepochopení ze strany 
žáků, kteří se cítí rozhodnutím učitele poškozeni. Hodnocení se pak stává stresovou situací jak pro žáky, tak pro učitele a výrazně zhoršuje tvưrčí atmosféru ve vzdělávacím procesu. Většina pedagogů se snaží takovým problémům zabránit a neustále hledá způsoby, jak zajistit, aby hodnocení žáků bylo co nejvíce objektivní. Jednou z možností je i využití informačních technologií, např. jazykového fuzzy modelování, které má napomoci kvalitnějšímu rozhodování učitelů při hodnocení žáků.

\section{Popis expertního systému}

Použijme základ myšlenky [1] a konstatujme, že expertní systémy jsou počítačové programy, simulující rozhodovací činnost experta při řešení složitých úloh a využívající vhodně zakódovaných, explicitně vyjádřených znalostí, převzatých od experta, s cílem dosáhnout ve zvolené problémové oblasti kvality rozhodování na úrovni experta.

Expertem je v našem př́padě učitel, který využivá všech svých objektivních i subjektivních znalostí, aby vyřešil daný problém, kvalitně ohodnotil úroveň znalostí a dovedností žáka. Totéž musí dokázat na srovnatelné úrovni, kvalitně vytvořený expertní systém. Hodnocení konkrétního žáka učitelem i systémem by mělo být adekvátní.

Expertní systémy můžeme klasifikovat podle různých hledisek. Např́íklad podle charakteru řešeného problému rozlišujeme expertní systémy diagnostické a plánovací. Plánovací expertní systémy řeší takové úlohy, kdy je znám cíl řešení a počáteční stav a je třeba $\mathrm{s}$ využitím dat o konkrétním řešeném prŕípadu nalézt posloupnost kroků, kterými lze cíle dosáhnout. Diagnostické systémy určují, která $\mathrm{z}$ hypotéz $\mathrm{z}$ předem konečné množiny cílových hypotéz nejlépe odpovídá skutečné situaci a shoduje se s daty konkrétního případu. Výsledkem jeho činnosti je seznam ohodnocených cílových hypotéz (diagnóz). Pro naše účely využijeme právě diagnostický expertní systém, který bude obsahovat stupně hodnocení (písmeny A - F) jako cílové hypotézy.

Struktura diagnostického expertního systému je uvedena na Obr. 1.

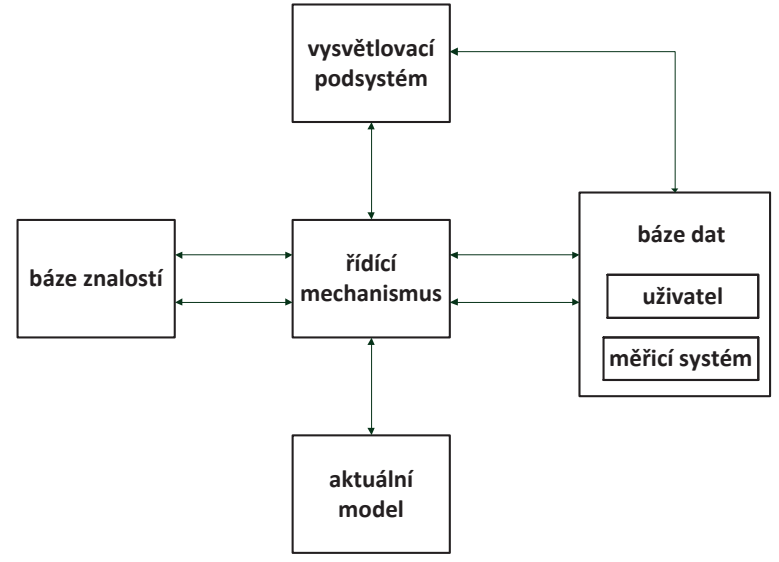

Obr. 1: Struktura diagnostického expertniho systému

Základem každého expertního systému je báze znalostí, která obsahuje celou škálu znalostí experta (expertů) od obecných, objektivních až po soukromé, subjektivní. Jde tedy o systém pravidel a heuristik, které jsou využitelné při řešení daných problémů. Znalosti mohou být reprezentovány různým způsobem nejčastěji v podobě obecného rozhodovacího pravidla (či soustavy pravidel) [3],[4], viz dále.

Jádro expertního systému tvoří báze znalostí a řídicí (inferenční) mechanizmus, který operacemi nad bází znalostí na základě aktuálních dat (dotazu) upřesňuje (aktualizuje) obecný model a vyvozuje odpověd' (závěr). Určuje tedy strategii využívání znalostí uložených v bázi znalostí.

Jak již bylo řečeno, expertní systém se snaží co nejpřsesněji napodobit rozhodovací činnost experta při řešení konkrétního problému. Báze znalostí představuje mentální model, který co nejpřesněji simuluje činnost člověka, odborníka $\mathrm{v}$ daném oboru. Expert řeší konkrétní problém díky svým znalostem. Systém zohlední konkrétní (aktuální) vstupní data $\mathrm{v}$ obecně formulovaných pravidlech báze znalostí a pomocí inferenčního mechanismu vyvozuje závěr. Množinu všech vstupních dat vztahujících se $\mathrm{k}$ danému príípadu nazýváme bází dat. Konkrétní data mohou být získána jako jazykové hodnoty od uživatele, prípadně přímým měřením jako numerické hodnoty nebo kombinovaně.

Uživatelsky významnou částí expertního systému je vysvětlovací podsystém. Ten poskytuje informace o konkrétním postupu, jímž bylo dosaženo závěru. Podává tak vysvětlení a odůvodnění svých rozhodnutí. Tak může uživatel sám posoudit kvalitu odpovědí expertního systému a případně dodatečně modifikovat své rozhodnutí. 


\section{Tvorba expertního systému}

Uvažujeme-li o problému vybudování počítačového systému, který by řešil daný problém stejně kvalitně jako expert, musíme vyř̌šit dvě základní úlohy [6]:

- jakým způsobem formalizovat $\mathrm{v}$ počítači subjektivní expertní znalosti, tedy jak formalizovat $\mathrm{v}$ počítači mentální model,

- na jakých principech vybudovat logické algoritmy, které budou nad těmito znalostmi operovat, s cílem jazykový model využít obdobným způsobem, jakým použivá svůj mentální model expert.

Počítačová reprezentace jazykových popisů vyžaduje použití takových metod, které umožňují formalizaci velmi důležité vlastnosti slov přirozeného jazyka, jejich prrirozené neurčitosti vágnosti. Pro formalizaci vágnosti bylo vyvinuto několik metod, z nichž k nejrozšířenějším patří metoda tzv. neostrých neboli fuzzy množin [1].

Pokusme se nejprve formalizovat vágní pojmy „nízká aktivita“ a „vysoká aktivita“ (myšleno aktivita žáka ve vyučovacím procesu) pomocí obyčejných množin. Předpokládejme, že hranice matematických intervalů nízké a vysoké aktivity je 5 bodů. To znamená, že aktivita 5 bodů je systémem ještě považována za nízkou, ale aktivita 5,1 je již vysoká. Situace je dána tím, že klasická množinová teorie zná pouze dvě hodnoty náležení prvku $x$ do množiny $\mathrm{A}$, a to 1 absolutní náležení, 0 - absolutní nenáležení, tedy

$$
\mu_{A}(x) \rightarrow[0 ; 1]
$$

Takto ovšem člověk neuvažuje a takový př́istup nelze u mentálních modelů použít, protože jej nelze považovat za inteligentní. V mentálních modelech používáme běžně pojmy jako „spíše nízká, ani nízká ani vysoká, téměř vysoká, velmi nízká" apod. Počítačově formalizujeme tyto neurčité pojmy fuzzy množinami (fuzzy znamená neurčitý, mlhavý, ne zcela přesně vymezený). Každému prvku $x$ $\mathrm{z}$ množiny $\mathrm{A}$ je přiřazen stupeň př́slušnosti, který je definován jako reálné číslo z uzavřeného intervalu $<0,1>$, tedy

$$
\mu_{A}(x) \in<0,1>
$$

Tímto krokem zachováme původní absolutní náležení nebo nenáležení (hraniční hodnoty 1 nebo 0) prvku do dané množiny, umožníme však také vyjádření náležení částečného, které můžeme libovolně kvantifikovat reálným číslem $\mathrm{v}$ otevřeném intervalu $0 \mathrm{a} 1$. Např. aktivita $x_{1}$ (viz
Obr. 2) je spíše vysoká, nebot' stupeň př́slušnosti do fuzzy množiny VYSOKÁ je 0,8

$$
\mu_{V Y S O K A ́}\left(x_{1}\right)=0,8
$$

a současně stupeň prŕíslušnosti $\mathrm{k}$ fuzzy množině NÍZKÁ je 0,2.

$$
\mu_{N \mid ́ Z K A ́}\left(x_{1}\right)=0,2 .
$$

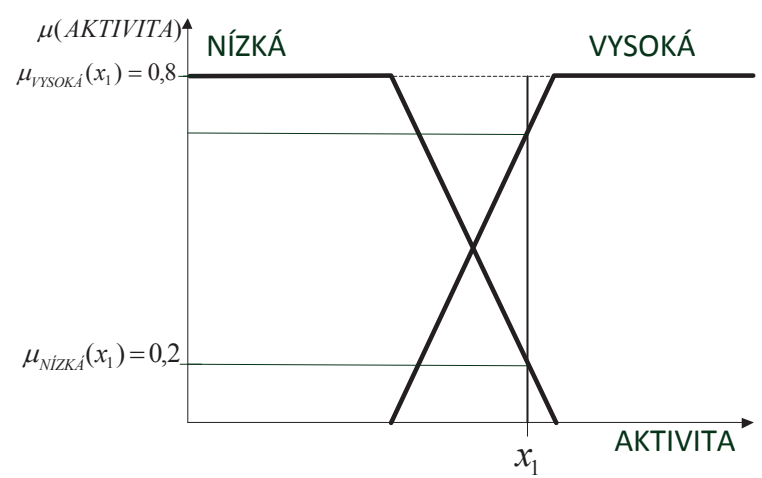

Obr. 2 - Fuzzy množiny jazykových hodnot NÍZKÁ a VYSOKÁ jazykové proménné AKTIVITA

Pomocí fuzzy množin tak můžeme velmi jednoduše vyjádřit stupeň vágnosti slovních pojmů.

V našem modelu hodnocení znalostí žáků budou některé vstupní proměnné formalizované numericky (napr. výsledek ústni zkoušky, písemné zkoušky, seminárni práce, účasti na cvičení), jiné jazykovým ohodnocením - kvalitativními slovními kvantifikátory (např. aktivita žáka, podmínky pro jeho studium). Systém má 6 vstupních jazykových proměnných a jednu jazykovou proměnnou výstupní s následujícími univerzy a jazykovými hodnotami:

\section{Jazykové proměnné vstupní}

\begin{tabular}{llll}
$\begin{array}{l}\text { Jazyková } \\
\text { proměnná }\end{array}$ & Id & $\begin{array}{l}\text { Rozsah } \\
\text { univerza }\end{array}$ & $\begin{array}{l}\text { Jazykové } \\
\text { hodnoty }\end{array}$ \\
\hline ÚSTNÍ & UZ & {$[0,30]$} & $\begin{array}{l}\text { NEVYHOVĚL } \\
\text { DOBŘE } \\
\text { ZKOUŠ́KA }\end{array}$ \\
& & & $\begin{array}{l}\text { VÝBORNE } \\
\end{array}$
\end{tabular}

$\begin{array}{lll}\text { PÍSEMNÁ } & \text { PZ } \quad[0,20] \quad \begin{array}{l}\text { NEVYHOVĚL } \\ \text { DOBŘE } \\ \text { ZKOUŠKA }\end{array} & \\ & & \text { VÝBORNĚ }\end{array}$

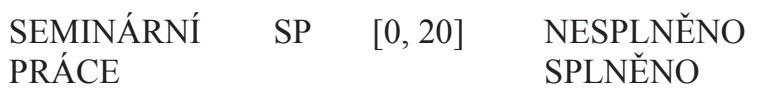

$\begin{array}{lll}\text { ÚČAST NA } & \text { UC } \quad[0,15] \quad \begin{array}{l}\text { NÍZKÁ } \\ \text { CVIČENÍ }\end{array} & \text { VYSOKÁ }\end{array}$

AKTIVITA AK $[0,10] \quad$ NÍZKÁ VYSOKÁ 


\begin{tabular}{|c|c|c|c|}
\hline $\begin{array}{l}\text { PODMÍNKY } \\
\text { STUDIA }\end{array}$ & PS & {$[0,5]$} & $\begin{array}{l}\text { PŘÍZNIVÉ } \\
\text { NEPŘÍZNIVÉ }\end{array}$ \\
\hline \multicolumn{4}{|c|}{ Jazyková proměnná výstupní } \\
\hline $\begin{array}{l}\text { Jazyková } \\
\text { proměnná }\end{array}$ & Id & $\begin{array}{l}\text { Ostré } \\
\text { hodnoty }\end{array}$ & $\begin{array}{l}\text { Jazykové } \\
\text { hodnoty }\end{array}$ \\
\hline \multirow[t]{6}{*}{ HODNOCENÍ } & $\mathrm{HO}$ & 1 & $\mathrm{~A}$ \\
\hline & & $1-$ & $\mathrm{B}$ \\
\hline & & 2 & $\mathrm{C}$ \\
\hline & & $2-$ & $\mathrm{D}$ \\
\hline & & 3 & $\mathrm{E}$ \\
\hline & & 4 & $\mathrm{~F}$ \\
\hline
\end{tabular}

Jazykové hodnoty vstupních proměnných i výstupní proměnné fuzzy modelu jsou $\mathrm{v}$ počítači reprezentovány fuzzy množinami s lichoběžníkovou aproximací (Obr. 3 - Obr. 9), jejichž parametry (body zlomu) jsou uvedeny v Tab. 1 - Tab. 7.

\begin{tabular}{|l|c|c|c|c|}
\hline \multicolumn{5}{|c|}{ ÚSTNÍ ZKOUŠKA (UZ) } \\
\hline NEVYHOVĚL & 0 & 0 & 7.5 & 13 \\
\hline DOBŘE & 7.5 & 13 & 18 & 25 \\
\hline VÝBORNĚ & 18 & 25 & 30 & 30 \\
\hline
\end{tabular}

Tab. 1 Parametry fuzzy množin jazykových hodnot proměnné USTNÍ ZKOUŠKA (UZ)

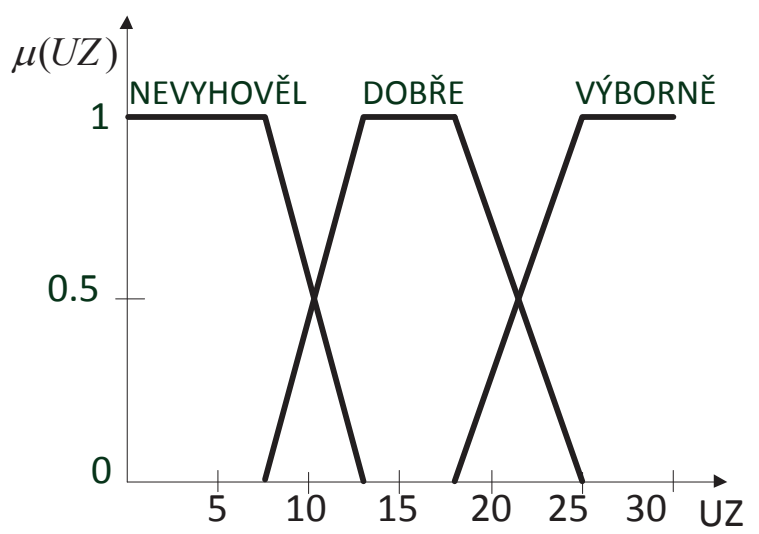

Obr. 3 - Tvary funkci přislušnosti fuzzy množin jazykových hodnot proměnné UZ

\begin{tabular}{|l|c|c|c|c|}
\hline \multicolumn{5}{|c|}{ PÍSEMNÁ ZKOUŠKA (PZ) } \\
\hline NEVYHOVĚL & 0 & 0 & 5 & 10 \\
\hline DOBŘE & 5 & 10 & 12 & 18 \\
\hline VÝBORNĚ & 12 & 18 & 20 & 20 \\
\hline
\end{tabular}

Tab. 2. - Parametry fuzzy množin jazykových hodnot proměnné PÍSEMNÁ ZKOUŠKA (PZ)

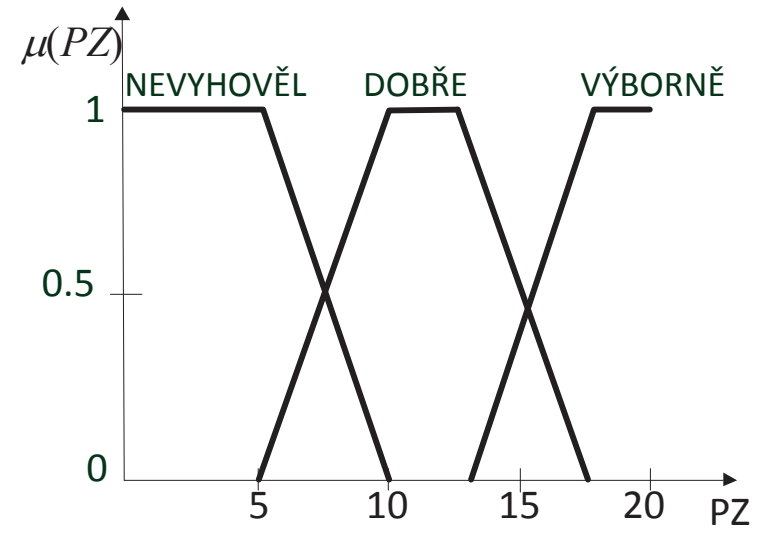

Obr. 4 - Tvary funkci př́slušnosti fuzzy množin jazykových hodnot proměnné PZ

\begin{tabular}{|l|l|l|l|l|}
\hline \multicolumn{5}{|c|}{ SEMINÁRNÍ PRÁCE (SP) } \\
\hline NESPLNĚNO & 0 & 0 & 7 & 13 \\
\hline SPLNĚNO & 7 & 13 & 20 & 20 \\
\hline
\end{tabular}

Tab. 3 - Parametry fuzzy množin jazykových hodnot proměnné SEMINÁRNÍ PRÁCE (SP)

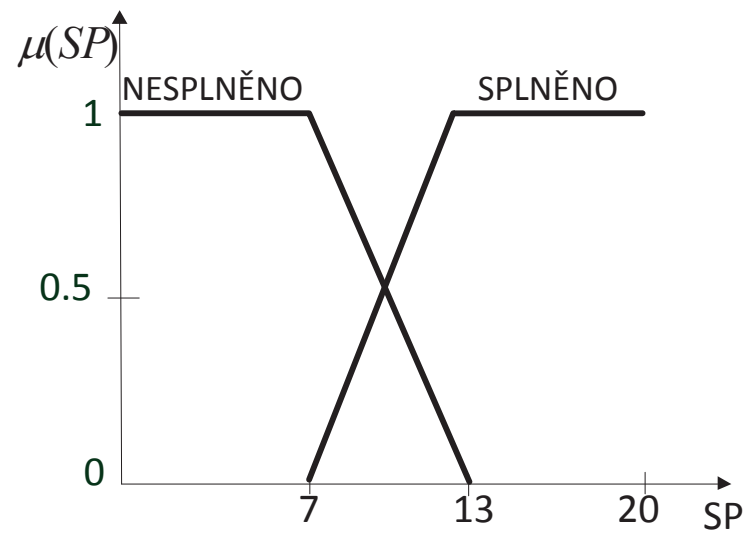

Obr. 5 - Tvary funkci př́slušnosti fuzzy množin jazykových hodnot proměnné SP

\begin{tabular}{|l|l|l|l|l|}
\hline \multicolumn{5}{|c|}{ ÚČAST NA CVIČENÍCH (UC) } \\
\hline NÍZKÁ & 0 & 0 & 7 & 12 \\
\hline VYSOKÁ & 7 & 12 & 15 & 15 \\
\hline
\end{tabular}

Tab. 4 -Parametry fuzzy množin jazykových hodnot proměnné ÚČAST NA CVIČENÍ (UC) 

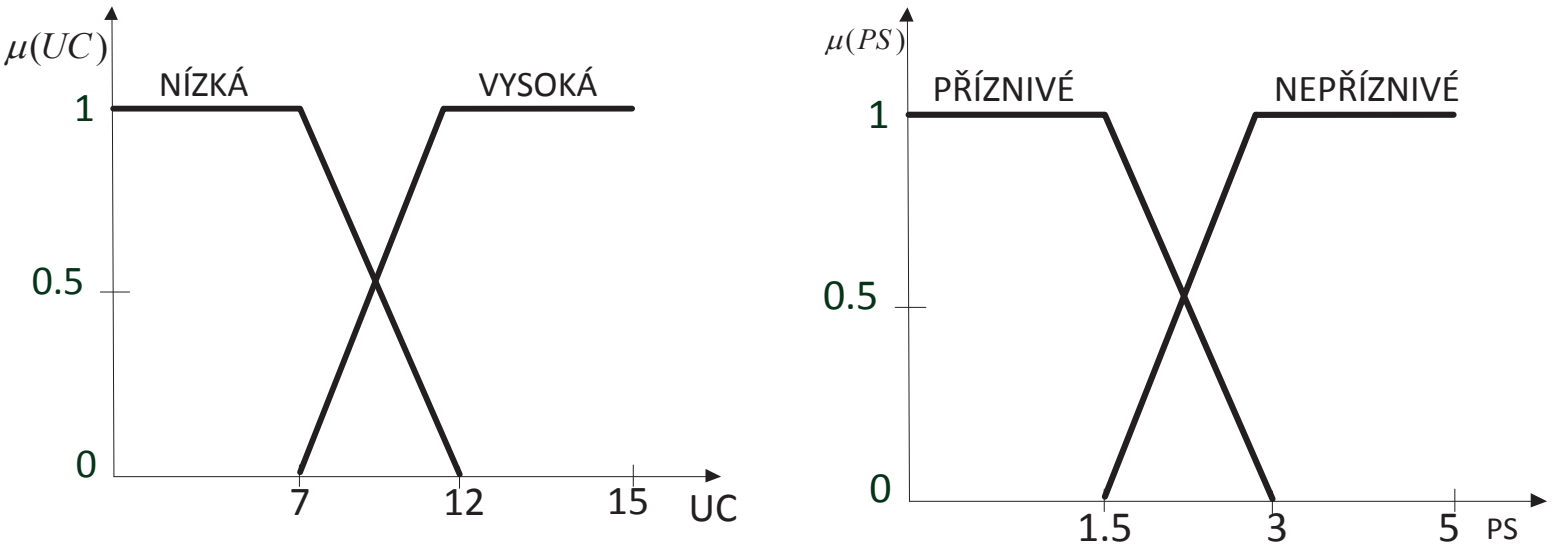

Obr. 6 - Tvary funkci přislušnosti fuzzy množin jazykových hodnot proměnné UC

\begin{tabular}{|l|l|l|l|l|}
\hline \multicolumn{5}{|c|}{ AKTIVITA (AK) } \\
\hline NÍZKÁ & 0 & 0 & 4 & 6 \\
\hline VYSOKÁ & 4 & 6 & 10 & 10 \\
\hline
\end{tabular}

Tab. 5 - Parametry fuzzy množin jazykových hodnot proměnné AKTIVITA (AK)

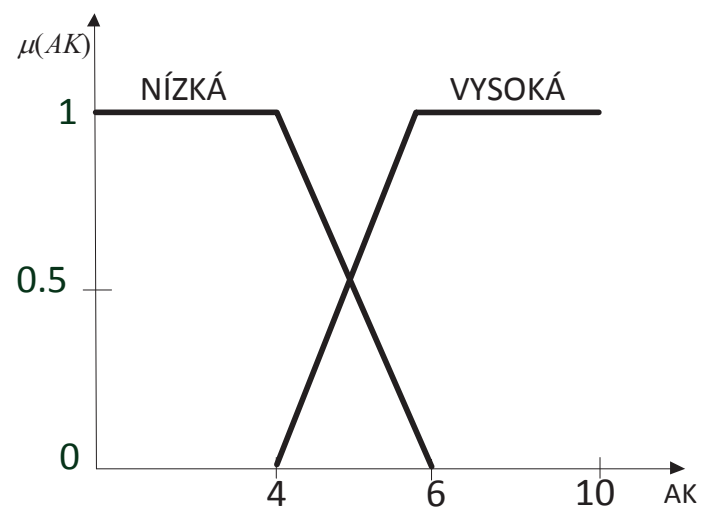

Obr. 7 - Tvary funkci př́slušnosti fuzzy množin jazykových hodnot proměnné $A K$

\begin{tabular}{|l|l|l|l|l|}
\hline \multicolumn{5}{|c|}{ PODMÍNKY STUDIA (PS) } \\
\hline PŘÍZNIVÉ & 0 & 0 & 1.5 & 3 \\
\hline NEPŘíINIVÉ & 1.5 & 3 & 5 & 5 \\
\hline
\end{tabular}

Tab. 6 - Parametry fuzzy množin jazykových hodnot proměnné PODMÍNKY STUDIA (PS)

Obr. 8 - Tvary funkci př̀slušnosti fuzzy množin jazykových hodnot proměnné PS

\begin{tabular}{|l|l|l|l|l|}
\hline \multicolumn{6}{|c|}{ HODNOCENÍ (HO) - závisle proměnná } \\
\hline F & 0 & 0 & 15 & 15 \\
\hline E & 17 & 17 & 32 & 32 \\
\hline D & 34 & 34 & 49 & 49 \\
\hline C & 51 & 51 & 66 & 66 \\
\hline B & 68 & 68 & 83 & 83 \\
\hline A & 85 & 85 & 100 & 100 \\
\hline Tab. 7 - Parametry obyčejných množin
\end{tabular}
jazykových hodnot proměnné HODNOCENÍ (HO)

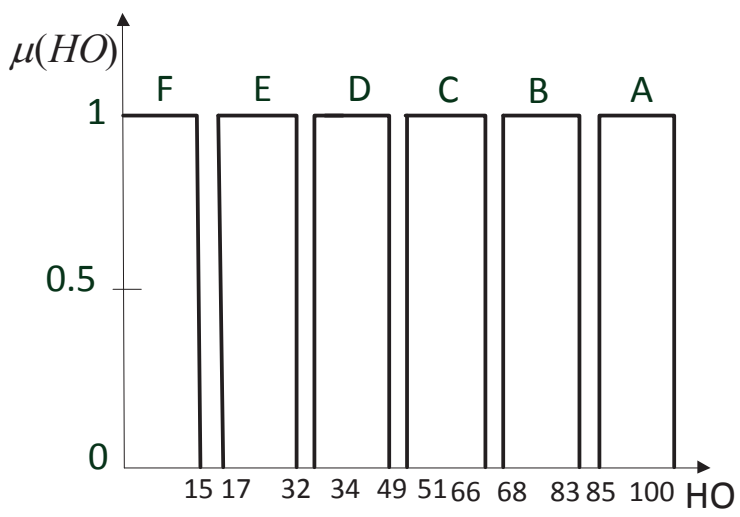

Obr. 9 - Tvary funkci přislušnosti obyčejných množin jazykových hodnot proměnné $H O$

Základem počítačových systémů pro simulaci myšlení experta je jazykový pravidlový fuzzy model. Zkušenost ukazuje, že jakoukoliv lidskou znalost lze vyjádřit pomocí jazykových pravidel typu JESTLIŽE-PAK (anglicky IF-THEN). Obecný tvar pravidla jazykového modelu je

IF ( $x$ je A) THEN ( $y$ je B)

kde výrok za IF je výrok o velikosti vstupní proměnné a nazývá se antecedent (podmínka, 
předpoklad), výrok za THEN odpovídá velikosti výstupní proměnné a nazývá se konsekvent (důsledek, závěr). Fuzzy pravidlo (3) vyjadřuje vztah mezi proměnnými $x$ a $y$ a dá se jednoduše interpretovat takto: Jestliže jazyková proměnná $x$ nabude své jazykové hodnoty $\mathrm{A}$, důsledkem je stav, kdy jiná jazyková proměnná $y$ nabude své jazykové hodnoty B.

Uvažujeme nyní situaci, kdy jazykovou proměnnou $x$ modifikujeme, bude mít hodnotu např. $A_{\mathrm{r}}\left(x\right.$ is $\left.A_{\mathrm{r}}\right)$. Ptáme se, jaké jazykové hodnoty $\mathrm{B}_{\mathrm{r}}$ nabude nyní modifikovaná jazyková proměnná $y$ ?

K získání odpovědi na tuto otázku je použit proces tzv. přibližného usuzování (aproximativní vyvozování). Jde o postup fuzzy logického usuzování a $\mathrm{k}$ jeho konstrukci je použito zobecnělé logické pravidlo fuzzy modus ponens (4) V něm jsou místo obyčejných výroků uvažovány fuzzy výroky [4]:

Podmínka: Jestliže ( $x$ je A) pak ( $y$ je B)

Premisa: $x$ je $\mathrm{A}_{\mathrm{r}}$

Závěr: $y$ je $\mathrm{B}_{\mathrm{r}}$

$\mathrm{V}$ prípadě modelu $\mathrm{s}$ více vstupními proměnnými jsou tvrzení o jejich velikosti v tzv. složeném (vícenásobném) antecedentu vázána logickou spojkou fuzzy konjunkce. V prrípadě popisu soustavy s $n$-vstupními a jednou výstupní proměnnou dostaneme soustavu $k$-pravidel ve tvaru:

$\mathrm{R}_{1}$ : IF $\left(\mathrm{x}_{1}\right.$ is $\left.\mathrm{A}_{11}\right)$ and $\left(\mathrm{x}_{2}\right.$ is $\left.\mathrm{A}_{21}\right)$ and ... and $\left(\mathrm{x}_{\mathrm{n}}\right.$ is $\mathrm{A}_{\mathrm{n} 1}$ ) THEN ( $\mathrm{y}$ is $\mathrm{B}_{1}$ )

$\mathrm{R}_{2}$ : IF $\left(\mathrm{x}_{1}\right.$ is $\left.\mathrm{A}_{12}\right)$ and $\left(\mathrm{x}_{2}\right.$ is $\left.\mathrm{A}_{22}\right)$ and ... and $\left(\mathrm{x}_{\mathrm{n}}\right.$ is $\left.A_{n 2}\right) \operatorname{THEN}\left(y\right.$ is $\left.B_{2}\right)$

$\mathrm{R}_{\mathrm{k}}$ : $\mathrm{IF}\left(\mathrm{x}_{1}\right.$ is $\left.\mathrm{A}_{1 \mathrm{k}}\right)$ and $\left(\mathrm{x}_{2}\right.$ is $\left.\mathrm{A}_{2 \mathrm{k}}\right)$ and ... and $\left(\mathrm{x}_{\mathrm{n}}\right.$ is $\mathrm{A}_{\mathrm{nk}}$ ) THEN ( $\mathrm{y}$ is $\mathrm{B}_{\mathrm{k}}$ )

Tvar výstupní modifikované fuzzy množiny $\mathrm{B}_{\mathrm{r}}$ při dosazení konkrétních hodnot proměnných $x_{1}$ až $x_{n}$ získáme vyvozovacím algoritmem využívajícím zákonů fuzzy logiky a pravidla fuzzy modus ponens. Vysvětlení této operace, nazývané fuzzy kompozice, vyžaduje hlubši znalosti fuzzy operací, které lze získat např. v [3], [4]

Konkrétně tedy pravidlová báze znalostí formalizující náś mentální model pro evaluaci znalostí má 144 pravidel, jejichž podmínkové části představují všechny kombinace jazykových hodnot vstupních proměnných. Jednotlivé kombinace byly expertně ohodnoceny přiřazením př́slušných jazykových hodnot výstupní proměnné HODNOCENÍ.

Např. pravidlo $R_{l}$ má tvar

$R_{l}$ : IF (UZ is NEVYHOVEL) and ( $\mathrm{PZ}$ is NEVYHOVEL) and (SP is NESPLNENO) and (UC is NIZKA) and (AK is NIZKA) and (PS is PRIZNIVE) THEN (HO is F)

a formalizuje tuto znalost:

Jestliže ÚSTNÍ ZKOUŠKA je nevyhovujicí, PÍSEMNÁ ZKOUŠKA je nevyhovujici, SEMINÁRNÍ PRÁCE nesplněna, ÚČ́AST NA CVIČENÍ je nizká, AKTIVITA je také nizká a PODMÍNKY STUDIA jsou príznivé, pak HODNOCENÍ znalostí je F (tedy nedostatečně).

Obdobně bychom mohli interpretovat i zbývajících 143 pravidel. Efektivita navrženého fuzzy modelu bude ověřena pomocí simulačních výpočtů.

\section{Verifikace znalostní báze fuzzy-expertního systému hodnocení žáků}

Simulační výpočty provádíme tak, že jako vstupy modelu zadáváme číselné hodnoty vstupních proměnných a model vyvozuje odpovídající hodnotu HODNOCENÍ. CCíselné velikosti hodnot vstupních proměnných byly zvoleny dle následující tabulky:

\begin{tabular}{|c|c|c|c|c|c|c|}
\hline Číslo pokusu & $\overline{\mathrm{UZ}}$ & $\mathrm{PZ}$ & SP & $\mathrm{UC}$ & $\overline{A K}$ & PS \\
\hline 1 & $\overline{0}$ & 0 & 0 & 0 & 0 & 0 \\
\hline 2 & 30 & 20 & 20 & 15 & 10 & 5 \\
\hline 3 & 15 & 10 & 10 & 7.5 & 5 & 2.5 \\
\hline 4 & 8 & 10 & 10 & 10 & 5 & 0 \\
\hline 5 & 25 & 15 & 18 & 12 & 8 & 2 \\
\hline
\end{tabular}

proměnných pro simulační pokusy

Na obrázcích 10 až 14 jsou ohodnocené hypotézy - tvary jazykových fuzzy množin výstupní proměnné HODNOCENÍ v systému LMPS (Linguistic Model Processing System), což je jeden $z$ programových prostředků určených k tvorbě jazykových modelů [3].

První dvě kombinace vstupních dat (viz první a druhý rrádek Tab. 8) byly zvoleny tak, aby bylo patrné, že expertní systém dokáže vyvodit i ostré jednoznačné výsledky (hodnocení $\mathrm{F}$ znamená, že žák má znalosti nedostatečné, hodnocení A odpovídá výborným znalostem, viz Obr. 10, Obr. 11). Třetí pokus (viz Tab. 8) ukazuje situaci, 
kdy jsou data zvolena jako střední hodnoty vstupních proměnných. Systém vyvodil hodnocení $\mathrm{C}$ až $\mathrm{E}$, což můžeme slovně interpretovat jako „asi D“ (viz Obr. 12). Př́ čtvrté simulaci vstupní data odpovídají znalostem slabého žáka. Systém správně vyvodil hodnocení E až F, slovně vyjádřeno „spíše E“ (viz Obr. 13). Poslední sada vstupních dat (viz Tab. 8) odpovídá výsledkům dobrého žáka. Systém vyvodil hodnocení $\mathrm{A}$ až $\mathrm{B}$, úroveň ohodnocení jednotlivých diagnóz interpretujeme jako „spíše B“ (viz Obr. 14). Můžeme tedy konstatovat, že náš expertní systém pro jazykové hodnocení znalostí žáka vyvozuje správné závěry.

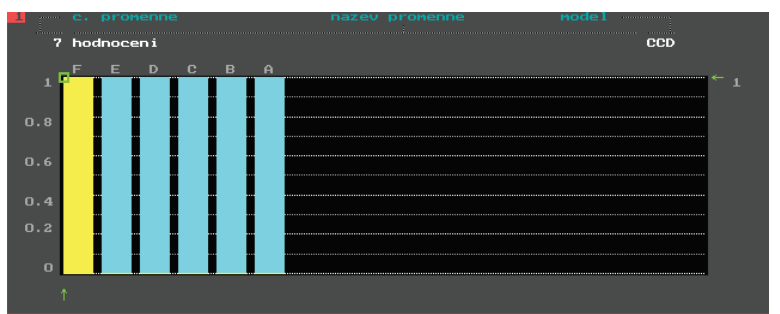

Obr. 10 - Simulačni interaktivní okno hodnocení $F$

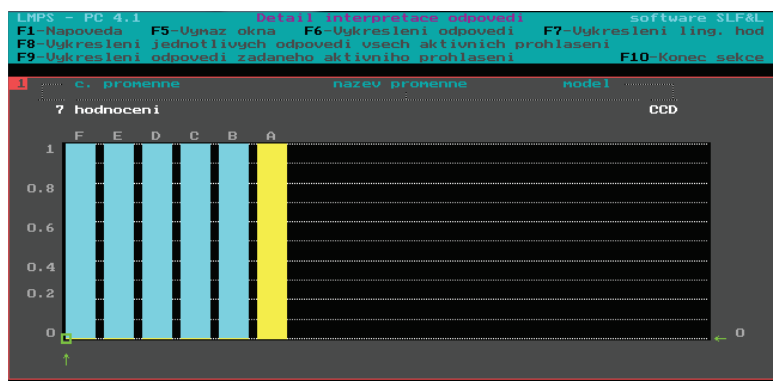

Obr. 11 - Simulační interaktivní okno hodnoceni A

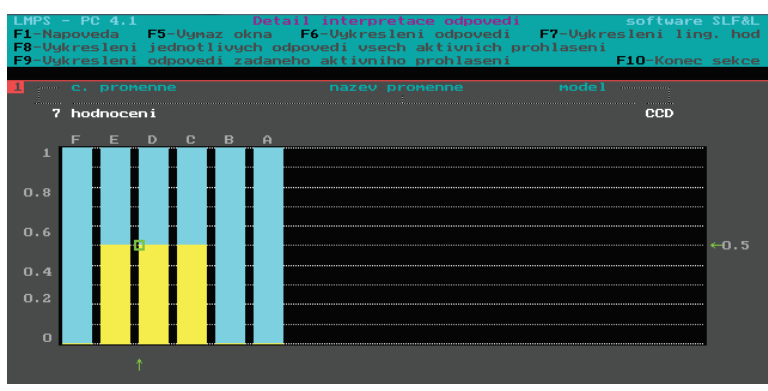

Obr. 12 - Simulační interaktivní okno hodnoceni $C$ - E

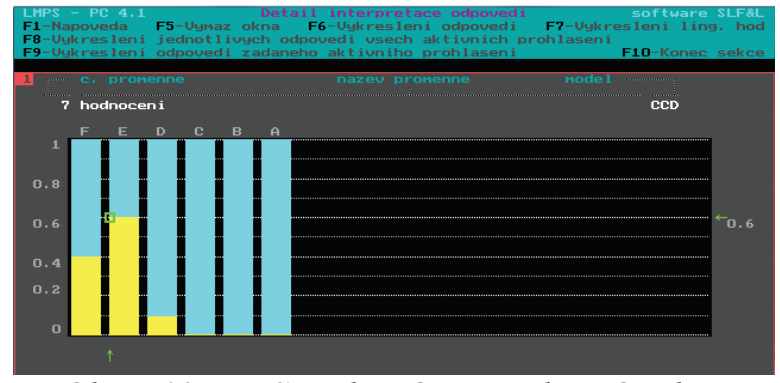

Obr. 13 - Simulační interaktivní okno hodnocení $E$ - $F$

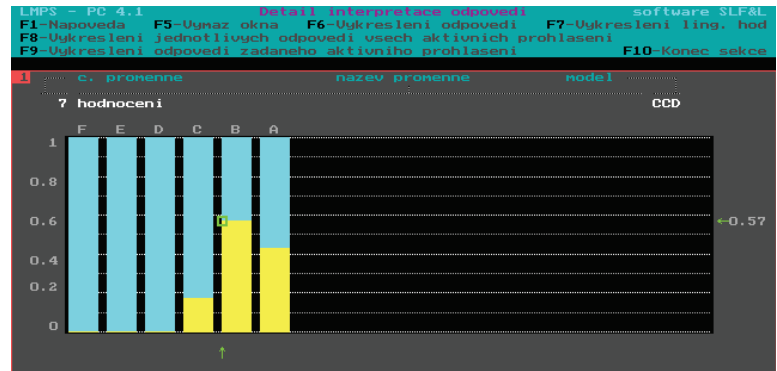

Obr. 14 - Simulační interaktivní okno hodnocení $A$ - $B$

\section{Závěr}

Hodnocení žáků je velmi zodpovědná a náročná práce, proto je třeba hledat nové způsoby, jak správně a objektivně posoudit individuální znalosti, schopnosti i dovednosti žáků. Jednou z nových možností je navržený fuzzy expertní systém pro hodnocení znalostí žáka, jehož výstupy (hodnocení) lze interpretovat slovně. Tento expertní systém bude jedním z online modulů systému ř́zení adaptivního procesu učení (systém ADEPT), jehož struktura byla představena na [7]. Systém bude testován na MVŠO v akademickém roce 2012/2013.

\section{Literatura}

[1] ZADEH, L. A Fuzzy Sets, Information\&Control, 8, 1965

[2] ČÍHALOVÁ, E. MAYER, I. Klasifikace a slovni hodnocení. 1. vyd. Edice Škola 21, Praha: Agentura STROM, 1997. 63 s. ISBN 80901954-6-6

[3] POKORNÝ, M. Umělá inteligence $v$ modelování a řízení. BEN Praha, 1996, ISBN $80-$

- 901984-4-9.

[4] NOVÁK,V. Základy fuzzy modelování, BEN Praha , 2000, ISBN 80-7300-009-1. 
[5] DVOŘÁKOVÁ, M.: Charakteristika slovního hodnocení. In: Slovni hodnocení. IUVENTA, Kroměříž 1994

[6] POKORNÝ, M., LAVRINČÍK, J., DOSTÁL, J. Počitačová formalizace mentálních modelů metodami jazykového fuzzy modelování. EMI Ekonomika, management, inovace. 2010, Olomouc - EU, Moravská vysoká škola, Volume 2, Issue 3, s. 17 - 29. ISSN 1804-1299

[7] KRIŠOVÁ, Z. Metody umělé inteligence ve vzdělávacím procesu. Sborník konference PRIT,
2012, České Budějovice, Jihočeská univerzita $\mathrm{PdF}, \mathrm{v}$ tisku.

Mgr. Zdeňka Krišová

Ústav informatiky, MVŠO, o. p. s.

Jeremenkova 42

77200 Olomouc

Tel: +420 587332392

E-mail: zdenka.krisova@mvso.cz 